\title{
The Social Embeddedness of MSMEs Goyor Woven Sarong in Sambirembe Village, Kalijambe, Sragen
}

\author{
Meita Arsita 1,* (D), Ahmad Zuber 2, (D) and Argyo Demartoto 2 (D) \\ ${ }^{1}$ Master of Sociology, Faculty of Social and Political Sciences, \\ Universitas Sebelas Maret, 57126, Surakarta, Indonesia \\ 2 Department of Sociology, Faculty of Social and Political Sciences, \\ Universitas Sebelas Maret, 57126, Surakarta, Indonesia \\ * Corresponding Author: meitaarsita28@student.uns.ac.id
}

\section{ARTICLE INFO}

\section{Publication Info: \\ Research Article}

How to cite:

Arsita, M., Zuber, A., E

Demartoto, A. (2020). The Social

Embeddedness of MSMEs Goyor

Woven Sarong in Sambirembe

Village, Kalijambe, Sragen.

Society, 8(2), 359-371.

DOI: 10.33019/society.v8i2.198

Copyright () 2020. Owned by Author(s), published by Society

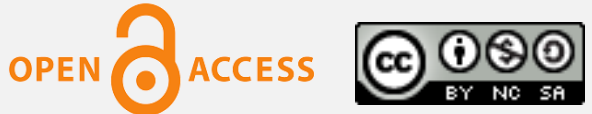

This is an open-access article.

\section{License: Attribution- \\ NonCommercial-ShareAlike (CC BY-NC-SA)}

Received: June 14, 2020;

Accepted: August 3, 2020;

Published: August 31, 2020;

\section{ABSTRACT}

Goyor woven sarong craft is one of the Micro, Small, and Medium Enterprises (MSMEs) in Wonosari Hamlet, Sambirembe Village, Kalijambe Sub-District, Sragen Regency, Central Java Province, Indonesia. The woven sarong craft is a cultural heritage passed down from generation to generation. The woven sarong craft business has survived even though the industrial-scale businesses have spread widely. In economic practice, economic actions among business actors of the woven sarong craft are based on cultural values. This research aims to analyze (1) the embeddedness of cultural values in economic practices of Goyor woven sarong; (2) the relational embeddedness between middlemen, collectors, and craftswomen; (3) the economic strategy of the Goyor woven sarong business. This research was qualitative research with a case study approach. The research analysis used the concept of economic actors' embeddedness in the social networks approach by Granovetter. Research data was collected through in-depth interviews and direct observation. Informants were selected using a purposive sampling technique. The result shows that: 1) there is the embeddedness of cultural values on the woven sarong craft business sustainability. Woven sarong craft is a cultural heritage and work ethic has become the main foundation for business sustainability; 2) the relational embeddedness was manifested through mutual trust between the collectors, middlemen, and craftswomen through a sense of "ewuh pekewuh" (feeling bad, embarrassment, feeling uncomfortable), and through mutual need between the collectors, middlemen, and craftswomen; 3) the economic

Copyright (C 2020. Owned by Author(s), published by Society. This is an open-access article under the CC-BY-NC-SA license. 
strategy of the Goyor woven sarong business actors follows the flow of community culture.

Keywords: Cultural Values; Economic Action; Goyor Woven Sarong; MSMEs; Social Embeddedness

\section{Introduction}

The development of Micro, Small, and Medium Enterprises (MSMEs) from year to year increases continuously. According to the Ministry of Cooperatives and Small and Medium Enterprises of the Republic of Indonesia, in the 2017-2018 periods, MSMEs increased by 1,271,440 or $2.02 \%$ (Kementerian Koperasi dan Usaha Kecil dan Menengah Republik Indonesia, 2018). The increasing trend in the number of MSMEs also occurred in Central Java Province. The Office of Cooperatives and Small and Medium Enterprises of Central Java Province recorded an increase in the number of assisted MSMEs with a total of 3,495 MSMEs. The increasing MSMEs in Central Java Province are as follows:

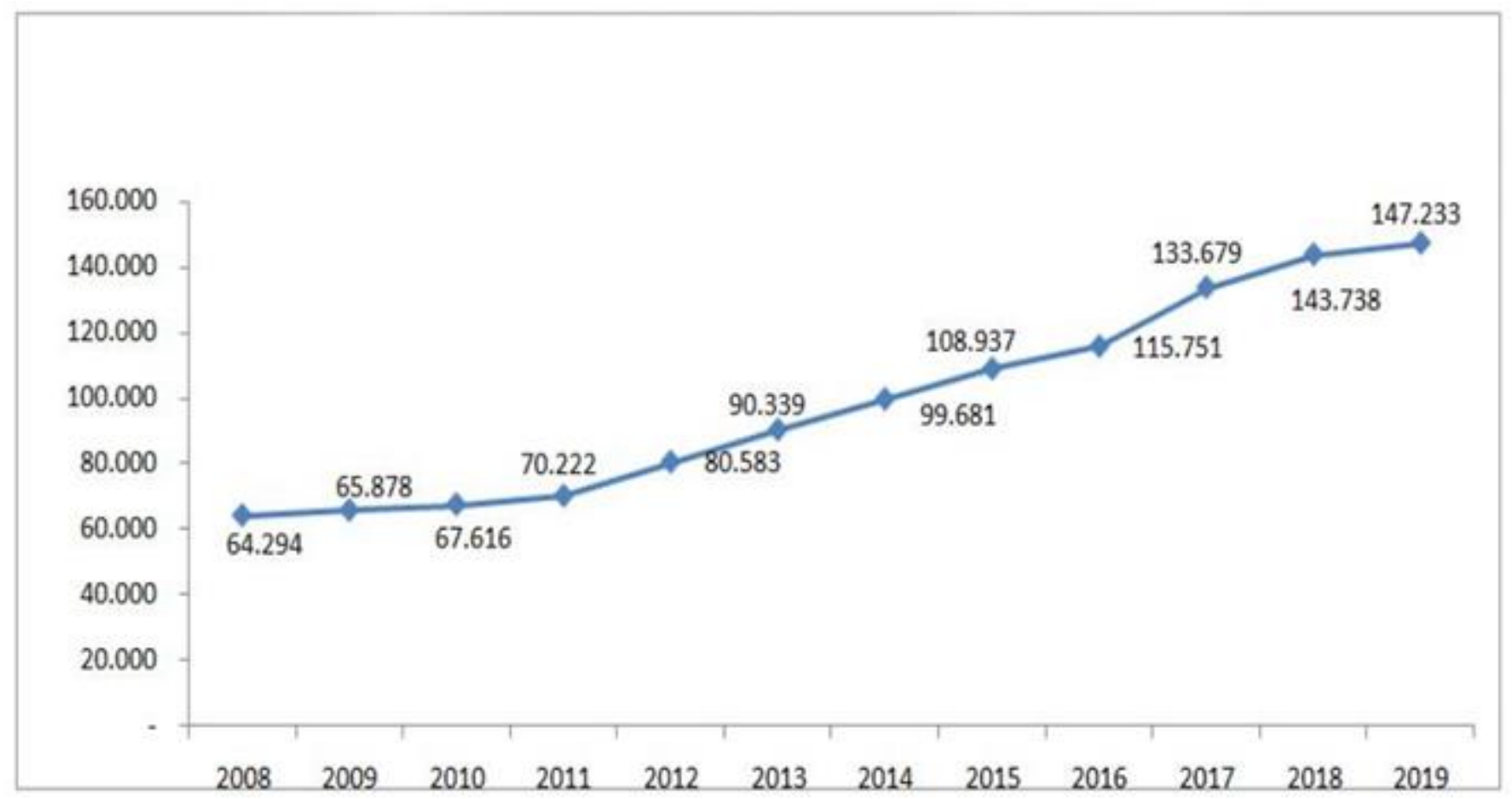

Figure 1. Graph of the Increase in the Number of MSMEs in Central Java Province Source: Dinas Koperasi, Usaha Kecil dan Menengah Provinsi Jawa Tengah (2019)

Goyor woven sarong craft is one of the Micro, Small, and Medium Enterprises (MSMEs) which is quite developed in Sragen Regency, Central Java Province. At least, 6 MSMEs have around 500 Goyor woven sarong craftsmen. Weaving is an activity to assemble the warp in the vertical position and the weft in the horizontal position. Weaving activities were inherited almost 100 years ago. According to Mbah Hadi (85 years old), in his early childhood, he was involved in the weaving process and marketing of Goyor woven sarongs in Sambirembe Village (Kementerian Perindustrian Republik Indonesia, 2018).

Goyor woven sarong produced by the community of Wonosari Hamlet is one of the featured products of Sragen Regency. The Goyor woven sarong is already on the international market, 
one of which is the Middle East. This has the advantage known as "toldem", which can be warm in cold weather and can also be cool in hot weather. The local wisdom of Goyor woven sarongs is increasingly prominent with the weaving process using traditional non-machine weaving tools (Alat Tenun Bukan Mesin or ATBM) in almost every house in Wonosari Hamlet. The majority of weavers are women.

The Goyor woven sarong craft still exists today. Even though now is the era of modernization, the Goyor woven sarong is still in demand. The era of modernization is marked by the development of industries, such as the establishment of various factories. The location of Wonosari Hamlet is not far from the furniture industrial area of the Indonesian Furniture and Handicraft Industry Association (Asosiasi Industri Permebelan dan Kerajinan Indonesia or ASMINDO) and not far from several factories such as the Menara cigarette factory and also Gudang Garam cigarette factory. However, this condition does not affect the sustainability of the Goyor woven sarong. Most of the residents of Wonosari Hamlet continue to carry out their profession as weavers. Uniquely, the natives and immigrants, who live in Wonosari Hamlet, will eventually choose to become weavers. This is very interesting because most residents of Wonosari Hamlet still prefer to weave instead of working in factories that have fixed wages. The economic action of the woven sarong business actors in Wonosari Hamlet is interesting to study. This research aims to examine the embeddedness of cultural values to the economic activity of the Goyor woven sarong, the relationship between the Goyor woven sarong business, and the economic strategy of the Goyor woven sarong business.

\section{Literature Review}

\subsection{Related Works}

Several studies on the theory of embeddedness have been conducted. In research from Rahayu (2019) showed that in the economic practice of selling Batik, woven sarong, and convection products at the Mlangi Islamic Boarding School, there is embeddedness on religious values and social networks. Business actors believe that work is not only about earning money but also as an activity to worship God and to build kinship and brotherhood with fellow human beings. The difference between Rahayu's research and this research lies in the object of research, where the object of Rahayu's research was the business owner, while the object of this research was the middlemen, colectors, and craftswomen of Goyor woven sarong in Sambirembe Village, Kalijambe Sub-District, Sragen Regency.

Besides, in another research conducted by Jamilah et al, (2016) showed that the embroidery business in Tasikmalaya embedded to religious values, including trustworthiness, honesty, and fairness, as well as Sundanese cultural values "silih asih, silih asah, silih asuh" (love one another, remind one another, guide one another). The difference between this research and the research conducted by Jamilah et al. lies in the type of business and location of the research. Every community has a unique culture; the culture of one community is not the same as another community.

Also, research from Hasan et al, (2020) showed the impact of social capital on economic attitudes and outcomes. In the economic activities of the Chinese lending industry, people with high social capital are easier to get loans, even loans in large amounts. Meanwhile, people who have low social capital experience difficulties in obtaining loans. This shows that social conditions have an impact on economic activity. Economic action does not always consider profit and loss but is also influenced by social factors.

Meanwhile, according to Hedberg \& Zimmerer (2020), there is social-ecological embeddedness in the economic practices of farmers and consumers in the United States. 
Farmers' concern for the safety of consumer products produced can generate consumers trust. Farmers provide information to consumers about changes in soil conditions and chemical fertilizers used so that consumers can know the safety and suitability of the agricultural food they will consume. Referring to the Local Food System Initiative (LFSI), farmers need to change the farming system to support a sustainable and ecological farming system.

In research from Rohadi (2012), the Goyor woven sarong craft is one of the tourism potentials in the Sragen Regency. The difference between this research and the research conducted by Rohadi lies in research focus. Rohadi's research focused on the tourism potentials, meanwhile this research focused on the social practice on the economic activity process based on Granovetter's social embeddedness theory approach. This research aims to examine the socio-cultural relationships that affect the sustainability of the woven sarong business in Wonosari Hamlet, Sambirembe Village, Kalijambe Sub-District, Sragen Regency, especially regarding the role of social aspects in economic practice among woven sarong business actors, and also, the role of culture in maintaining the woven sarong business in the industrialization era.

\subsection{Theoretical Framework}

Granovetter agreed with Webber that economic activity was not seen as a simple stimulusresponse phenomenon, but rather the process performed by individuals in the sustainable process of social relations (Damsar \& Indrayani, 2009). It meant that there were social practices embedded in the economic activities of the community. Cultural values could be embedded in the economic process and influence it.

The contemporary sociological perspective assumed that the actions of individuals in the economy are influenced by social bonds, which are embedded in the context of the social and cultural structures in which the community lives. Thus, economic activity is not always rational-calculative (Suyanto, 2013). This argument was in line with Granovetter's embeddedness concept. Embeddedness was interpreted as a socially situated and embedded economic action in a sustainable personal social network among actors (Damsar \& Indrayani, 2009). According to Granovetter $(1985 ;$ 1992) as cited in Jamilah et al, (2016) argued that every economic activity in (modern) industrial society also had social embeddedness non-economic institutions like religion and culture even though its embeddedness was on the strong (overembedded) and weak (under-embedded) continuum line.

Over-embedded took place when economic relations were strengthened by social relations between actors. Meanwhile, under-embedded did not have a close social relationship between actors. Granovetter in "The Old and the New Economic Sociology" distinguished embeddedness into two:

\subsubsection{Relational Embeddedness}

Relational embeddedness was socially situated and embedded economic action in a sustainable personal social network among actors. Granovetter described the relational embeddedness in the relationship between seller and buyer in customers relationships. When economic actors had reached the stage of definite and accurate information sharing and involving trust, the relationship between buyers and customers not only includes economic action but also extends to social, cultural, and political aspects (Damsar \& Indrayani, 2009). 


\subsubsection{Structural Embeddedness}

Structural embeddedness occurred in a wider network of relationships that could include institutions or social structures. The concept of social institutions involved a social structure that provided a ready-made arrangement for solving fundamental humanitarian needs. The social structure was a pattern of relationships or interactions organized in a social space like relationships in the Indonesian Doctors Association (Ikatan Doktor Indonesia or IDI) (Damsar \& Indrayani, 2009).

In economic perspective, new institutions have two views, include: (a) the mainstream of the economy must relate to institutions (b) the analysis of neglected institutions can be used directly based on classical economic principles. It is different from a rational choice approach that sees that human actions have intentions and objectives that are guided by a neatly organized hierarchy of preferences. The primary thinking is (a) the actor calculates the utilization or preference in choosing a form of action; (b) the actor also calculates the costs for each path of behavior; (c) the actor tries to maximize the utilization to obtain particular choices.

\section{Research Methodology}

This research was qualitative research with a case study approach. According to Creswell (1998) as cited in Juliansyah (2011) suggested that a qualitative research approach as a complex picture, examined words, detailed reports from the respondents' perspectives, and conducted studies on natural circumstances. The key emphasis of case studies was why individuals did what they did and how they behaved in various situations and their effects on the environment (Juliansyah, 2011). This study sought to provide an in-depth analysis of the influence of community culture on the economic actions of the Goyor woven sarong business so that it continued to survive despite the entry of industrialization.

This research was conducted in the Wonosari Hamlet, Sambirembe Village, Kalijambe SubDistrict, Sragen Regency, Central Java Province, Indonesia. The research was conducted from May to June 2020. The data used involved primary and secondary data. Primary data was obtained or collected directly from the data source. It was also called original or new data that was up to date, while secondary data was obtained or collected by the researchers from various existing sources or in other words, the researchers as a second hand (Salim, 2019). Primary data were obtained through in-depth interviews and direct observation of the weaving craftswomen. Besides, the research used secondary data obtained from journals, the internet, and informants' documents.

Informants were selected through purposive sampling technique. There were 7 informants selected, including 1 Head of the Neighborhood Association (Rukun Tetangga or RT) of the Wonosari Hamlet, 3 craftswomen of Goyor woven sarong, 3 collectors of Goyor woven sarong, and the Department of Industry and Trade of Sragen Regency. The Head of RT was chosen because he understood the ins and outs of the Goyor woven sarong and Goyor weaving activists as business actors Goyor woven sarong. The Department of Industry and Trade of Sragen Regency was chosen because it serves as an associate of MSMEs Goyor woven sarong in the Wonosari Hamlet and understands the sustainability of the MSMEs Goyor woven sarong. Meanwhile, the craftswomen were chosen as the primary social capital in the sustainability of the Goyor woven sarong business. The selected craftswomen were seen from the length of time they have worked as a weaver. The research was analyzed through interactive analysis from Miles and Huberman. Data analysis was done through data collection, data reduction, data presentation, and conclusions. The analysis of qualitative data was conducted interactively and continuously until complete so that the data had been saturated. Data analysis was done when

Copyright (C 2020. Owned by Author(s), published by Society. This is an open-access article under the CC-BY-NC-SA license. https://doi.org/10.33019/society.v8i2.198

363 
data collection took place and after completion of data collection in a certain period (Sugiyono, 2016).

\section{Results and Discussion}

\subsection{The Embeddedness of Community Cultural Values in the Weaving Business}

Embeddedness was interpreted as socially situated and embedded economic action in a sustainable personal social network among actors (Damsar \& Indrayani, 2009). Granovetter saw that economic activity in (modern) industrial society also had social embeddedness noneconomic institutions like religion and culture even though its embeddedness was on the strong (over-embedded) and weak (under-embedded) continuum line (Jamilah et al., 2016).

In the economic practice of the Goyor woven sarong business in Wonosari Hamlet, Sambirembe Village, Kalijambe Sub-District, Sragen Regency, there were cultural values inherent in it, which include:

\subsubsection{Weaving was the legacy of the ancestors maintain by the community}

The Head of RT explained that weaving was a hereditary legacy that had been performed about 3 generations or around 100 years ago. Almost all housewives are good at weaving. In their daily life, children see their mother's weaving activity and learn how to weave. Even in the past, there was the philosophy of "dudu wong wadon Wonosari yen durung biso nenun", which meant someone was not a Wonosari woman if not skilled at weaving. Weaving is an embedded socio-cultural activity in the Wonosari community. Although some of the weavers come from outside Wonosari Hamlet, most of them are women who move to Wonosari Hamlet because they follow their husbands.

Both native and migrant women in Wonosari would eventually weave because they saw the weaving process repeatedly. The Wonosari native woman who eventually had to follow her husband to move to another area did not leave the weaving activity. They continued to weave because it was part of the community culture. Therefore, woven products became the primary commodity of the Wonosari community.

\subsubsection{The Sense of "ewuh pekewuh" when not working}

A high work ethic was an embedded value in the Wonosari community. A Javanese philosophy of "ora obah ora mamah" which means if someone does not make any effort, the money will not be earned for daily needs. This philosophy served as a guideline for the community to be productive not only to rely on one family member as the financial support. Weavers admit that their weaving activity was driven by a sense of "ewuh pekewuh" (feeling bad, embarrassment, feeling uncomfortable) towards their neighbors who also weave. The Head of the RT of Wonosari Hamlet stated that almost every house had weave tools and almost rarely of them were unemployed.

People who did not weave would feel bad if they went to a weavers' place did not do anything. One of the craftswomen, EN, revealed that she felt confused about choosing activities that could be done at home if she was not working. She chose to weave because she felt bad (pekewuh) when visiting neighbors who were weaving. After all, it would disturb the neighbors. ST, another informant, also said the same thing as EN. ST, who has 3 children, chose to become a weaver because she felt bored if she did not work at home. Meanwhile, when she visited a neighbor's place, she was afraid that she would interfere with the work of that person. Thus, they would join in weaving to increase family income.

Copyright (C 2020. Owned by Author(s), published by Society. This is an open-access article under the CC-BY-NC-SA license. 
Feeling bad (ewuh pekewuh) could be seen as a social factor that drives economic activity. Economic activity is not only for earning maximum profit. The weavers' actions could be seen as irrational. People work for money. However, the Wonosari community did weaving more primarily driven by a sense of "ewuh pekewuh".

Income was considered a bonus from what they did as many women earn a little income from weaving. They consider weaving as a "samben", which was a part-time job besides taking care of household matters. PW, one of the weaving craftswomen expressed that her income from weaving was not much. She chose to weave because it gave positive activities for her at home rather than daydreaming. The earning they obtained were not the main point because the important thing was that they remain productive and did not intervene with their neighbors. Therefore, it could be seen that cultural influence was highly strong in people's economic actions.

\subsubsection{Comfort in Weaving}

There was a steady pattern in the Wonosari Hamlet community. Women learned to weave from their parents from childhood to adolescence. When finished school, some of them chose to go to the factory to work and gain experience, but when they were married, they would return to weaving. This was stated by PW. She claimed to have worked in a factory when she was young, but in the end, chose to weave after marriage. She felt that working in a factory was bound by many rules, different from weaving at home. She could still complete household chores while earning as a weaver. Furthermore, she told that many young people worked in factories before marriage, but after marriage, they were uncomfortable with the factory rules. Women who had experience weaving would feel more comfortable being weavers than working in a factory.

Weaving was the ultimate purpose of the community. In the view of rational choice theory by James Coleman, individuals try to maximize profits (Coleman \& Fararo 1992). Women who weave at home still earn while taking care of household duties. Meanwhile, when they only went to the factory, household affairs would be disordered. By choosing to become a weaver, they had calculated the profit and loss. If they worked in factories, they would be pressured by binding rules and did not have much time to manage the household. Meanwhile, being a weaver was more flexible because it could be done at any time so that it did not interfere with household chores.

People who were comfortable in weaving usually did not want to change jobs anymore. Weaving is not yet able to provide high income, but a sense of comfort and acceptance is the economic motive of the community. EN revealed that "menenun ora nyukupi tapi nguripi", which means that weaving could not provide excess sufficiency for the community, but they can survive from the outcome of weaving. It had been proven that many people had the main income from weaving. EN also revealed that she had worked in a furniture factory before weaving but chose to leave it because she was not comfortable with binding factory regulations.

There were various values given by weaving. Weaving practiced patience. The complexity of weaving equipment and machinery forced the weaver to be patient because if they were not, the weaving would be poor or rough. The Department of Industry and Trade of Sragen Regency stated that there were two keys to weaving, including not being color blind and patient. Furthermore, they revealed that the patience of the craftswomen in Wonosari was shaped by cultural factors handed down by ancestors. This patience in weaving produced good quality weavings that were difficult to find in other areas. 
Furthermore, there was a sense of belonging and respect among the weavers. One of the weavers admitted that when the number of weaving orders was limited, the other weaver was willing to give the weaving order to weavers who need more income. PW said that when there was no woven material due to material delays or the collectors had an event, she often gave up woven material for other weavers who were more in need. She felt that it was important to understand each other's weavers' conditions.

Weaving businesses would not be able to survive up to today if the community did not maintain this culture. Maintaining ancestral heritage, work ethic, "ewuh pekewuh" culture, and the comfort of weaving were over-embedded cultural values in community economic actions. Amid the siege of industrialization, however, the business performed with traditional tools had survived because of the cultural value maintained by the community.

\subsection{Relational Embeddedness of Middleman, Collectors, and Craftswomen}

The economic practice of the Goyor woven sarong business had 3 main actors including middlemen, collectors, and craftswomen. Middlemen were the capital owner such as NonMachine Weaving Tools (Alat Tenun Bukan Mesin or ATBM), money, and an extensive economic network (export capability). Usually, they came from Solo. Collectors were Wonosari people with social network capital to the middlemen, connecting the middlemen with the craftswomen. Meanwhile, craftswomen are workers who had labor capital, received wages, and follow the applicable rules.

In the past, the weaving business was performed entirely only by the people of Wonosari Hamlet. Starting from 14 weaving stages to marketing were done independently. However, as the next generation could do 14 stages of weaving, the pattern of the Goyor woven sarong business changes. The primary actors include the middleman as the owner of capital in Solo. They distributed their capital to collectors to get workers (craftswomen). In the capitalist economic system, the division of class and labor of business actors of the Goyor woven sarong could be seen in this following chart:

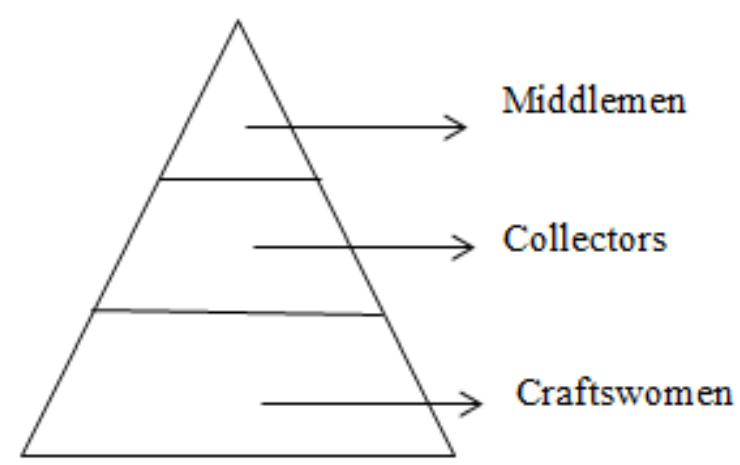

Figure 2. Division of Goyor Woven Sarong Working Class

Source: Primary Data (2020)

There is a strong and weak relational embeddedness between middlemen, collectors, and craftswomen.

\subsubsection{Relational Embeddedness of Middlemen \& Collectors}

The relationship between middlemen and collectors was not developed easily. The middleman did not give the weaving project to someone they did not know yet. One of the 
collectors, PM, claimed that not just anyone could become a collector. A collector must approach to gain trust. He was given the trust after 14 years of working for the weaving middlemen in Solo. They must be able to convince the middleman that they could get employees. There was a trust built between the middlemen and collectors. It is following Granovetter's statement that the buyer relationship became a customer when between economic actors had reached the stage of certain and accurate sharing of information and involved trust.

The relationship between buyers and customers not only included economic action but also extended to social, cultural, and political aspects (Damsar \& Indrayani, 2009). Likewise, the relationships between middlemen and collectors were formed by a sense of trust and closeness. PM admitted that the middleman also came to her house when her husband died. The Department of Industry and Trade of Sragen Regency also revealed that social factors influenced the sustainability of the MSMEs Goyor woven sarong. Craftswomen who had a ceremonial were usually lent money or other needs after the collectors provided information about the needs of the craftswomen. Money refunds were given in the form of weaving services. Every certain period, the weaver's salary was deducted to return the money. It showed that the relationship between middlemen and collectors was not only limited to the transactional relationship but extended to the social relationship.

\subsubsection{Relational Embeddedness of Collectors \& Craftswomen}

In Wonosari Hamlet, there were many collectors with a different middleman. Based on information from the Head of the RT, Wonosari Hamlet had approximately 10 collectors. These collectors had different middlemen. Collectors did not drop each other or seize craftswomen. Craftswomen who had settled on one middleman would not be taken by other collectors because they had been bound by a sense of mutual ownership between the middleman and the craftswomen. DM, one of the new collectors in Wonosari, provided training to people outside of Wonosari to obtain new weavers because, in the village, each weaver already had collectors. The same thing was conveyed by EN. DM was willing to accept new weavers who wanted to learn or who were only part-time workers (samben) because of the difficulty in finding full-time weavers. This was because the craftswomen had their collectors, so he did not dare to take the weavers.

Craftswomen came with collectors because of geographical factors. The craftswomen would join the collectors with close location to their house because there was a sense of "pekewuh" (feeling bad) if there were close collectors but the craftswomen chose the far away ones. The community did not want to bring up a sense of social jealousy. If the economic motive became the main motive, surely the craftswomen would choose the collectors who offered the highest wages. However, cultural values were more essential as a driving force for their socioeconomic actions. For them, life was not enough to prioritize money because harmonious neighboring lives were more comfortable. Therefore, the proximity of the location between collectors and craftswomen influenced the economic actions of the community.

\subsubsection{Relational Embeddedness of Middlemen \& Craftswomen}

The relationship between middlemen and craftswomen was bound through the savings and lottery system. Not all wages were given to the craftswomen. For instance, a wage of one woven sarong was Rp60,000, but the craftswomen received Rp50,000, while the Rp10,000 would be saved and issued during Eid. Furthermore, once a year, a meeting of all weaving craftswomen was held and there were lottery prizes such as household equipment and Umrah. Communication between the craftswomen and the middleman was done through the collectors.

Copyright (C) 2020. Owned by Author(s), published by Society. This is an open-access article under the CC-BY-NC-SA license. https://doi.org/10.33019/society.v8i2.198 
The complaint, if any, was given through a Warning Letter seen from the presence data of each craftswoman.

The relationship between the middlemen and the craftswomen was not too close because the interaction was not directly between the middleman and the craftswomen, but was carried out through the collectors. MJ, one of the collectors in Wonosari, said that the weaving was given to him every 1 week. After all the weavings were collected, he would give the weavings to the middlemen in Solo. Furthermore, PW explained that the medium of communication between the middlemen and the craftswomen used attendance books and warning letters. PW claimed to have been given a warning letter because of the small number of weavings. It was known from the absent number that she filled in every time she produced woven sarong. Attendance was done at the collectors' place.

The relationship between middlemen, collectors, and craftswomen was bound by a sense of mutual need. Therefore, their relationship was bound by moral ethics. The middlemen could not force the craftswomen to produce certain pieces of sarong since the majority of the weavers were women. However, the craftswomen also realized that they had the responsibility to give something (woven sarong as a result) because they felt pity for the collectors if they were unable to deposit.

This mutual need became the main factor in the sustainability of the Goyor woven sarong business. The relationship between middlemen, craftswomen, and collectors was not a relationship between superiors and subordinates which gave a social distance between them. The relationships were built more on family relationships that needed each other. DM explained that he was not targeting the weavers. The more produced, the more income would be get by the weavers. Meanwhile, PW explained that as a craftswoman who had received a warning letter, she tried to remain responsible for producing woven sarong. It shows the absence of social distance, different from factories that had a hierarchical management structure.

\subsection{Economic Strategy of Goyor Woven Sarong Business}

The Goyor woven sarong business could survive amid industrialization being inseparable from the embedded values in the community. Some conditions must be adjusted by the middlemen with the culture of the community. It was because the community was a giant arena where everyone tried to obtain social approval (Hafidz, 2015). Strategy based on economic morale was performed by business actors so that the existence of the Goyor woven sarong business continued to survive. The strategy included:

\subsubsection{Following the Culture of the Community}

Life in the village often had various social activities. These activities made the weavers unable to produce woven sarong. Neither middlemen nor collectors could force targets under these conditions. The Head of RT said that in the harvest season, the craftswomen would usually leave their weavings and chose to go to their paddy fields to take care of their fields or contribute to the work of neighboring fields. If there was a celebration or an activity to visit the sick, weavers could not weave. Collectors and middlemen inevitably had to accept this condition because the main resource was weavers in Wonosari Hamlet. Therefore, they must follow these conditions. If the collectors imposed the craftswomen, they were afraid the craftswomen would not want to weave anymore because Wonosari Hamlet was the center of weaving craftswomen. Nevertheless, it did not make the craftswomen ignore them. They still tried to give in the results they would because they felt that they had the responsibility after

Copyright (C 2020. Owned by Author(s), published by Society. This is an open-access article under the CC-BY-NC-SA license. https://doi.org/10.33019/society.v8i2.198 
being given the trust of weaving. They felt sorry for the collectors when they could not deposit to the middlemen.

Some conditions did not allow women to be demanded to produce more woven sarongs because they had a double burden. They performed their role as housewives before weaving. Inevitably, the collectors and the middlemen might understand this situation. Therefore, the work did not solely mean profit, but collectors tried to provide employment opportunities for women to remain economically independent while continued to perform their obligations as a housewife. Even when there were social events, weaving productivity was reduced. It could be understood by the collectors because they were also part of the community. Thus, they must follow what the community had agreed.

\subsubsection{Sense of Family}

The relationship between collectors and craftswomen was bound by a sense of kinship, not the kind of class between superiors and subordinates. Collectors and craftswomen mutually understood each other. In particular circumstances, such as social events and harvests, the craftswomen could not produce a lot of woven products. This condition was understandable for collectors. However, the craftswomen also felt that they had a responsibility to continue to weave for the sake of sustainable good economic relations between the middlemen and collectors. This was conveyed by the Head of the RT that there were social conditions that needed to be understood by the middlemen. The harvest time, celebration, or visiting the sick were social situations in the village that must be followed by the community. Therefore, in this condition, weavers could not do weaving activities.

In general, the craftswomen chose to join the collectors located close to their house. There was a sense of "pekewuh" (feeling bad) when they choose collectors who were far away, not the close ones, even though the wages were different. There was a sense of maintaining relations between neighbors in economic transactions they performed.

\subsubsection{Gift}

The wages paid to the craftswomen were not the whole. Extra money was saved for the craftswomen's savings. Besides, there was also the provision of basic food and lottery of prizes for household equipment and Umrah to bond the relationship between the middlemen, collectors, and craftswomen. This strategy could attract craftswomen to remain weavers. They felt happy when they got savings money, a holiday allowance (Tunjangan Hari Raya or THR), and prizes annually. Craftswomen would feel happy with the results of weaving. Therefore, it was very rare for women to leave weaving activity and chose to work in another place such as a factory.

\subsubsection{Trust}

The collectors could not carelessly sell woven products in retail or wholesale to the public or other middlemen. Each collector had been bound by one middleman. MJ and PM said that they could not sell the results of woven sarong to others. All woven products must be deposited to the middlemen. Even when the products were bought at a high price, they would not dare sell woven products to others. They maintain good relations with the middlemen because, in a weak selling power, they did not need to worry about the woven products. The middlemen guaranteed that the products were sold. Trust given by the middlemen to the collectors was closely maintained by the collectors. They need each other. Without the 
middlemen, the collectors could not sell woven products. Similarly, middlemen without collectors would not get woven products for sale.

Based on the above elucidation, it could be seen that cultural values served as the main foundation in maintaining the sustainability of the Goyor woven sarong business. In the embeddedness's view, a person would be embedded when the traditions became the basis of relations, particularly economic relations. Conversely, disembeddedness, when these traditions experienced disintegration and social change, brought the community away from tradition (Haryanto, 2011). Cultural values, a sense of family, and trust presented strong social embeddedness in the economic actions of the people of Wonosari Hamlet, Sambirembe Village, Kalijambe Sub-District, Sragen Regency.

\section{Conclusion}

Economic activities of MSMEs of Goyor woven sarong can survive because it upholds the cultural values of the local community. It can be concluded that economic activity is embedded in cultural values. Weaving as a legacy across remains preserved up to today, with a firmly embedded work ethic in the community. The relational relationship between the middlemen, collectors, and craftswomen is manifested in a sense of "ewuh pekewuh" (feeling bad, embarrassment, feeling uncomfortable). Meanwhile, the moral economic strategy becomes the primary foundation for the sustainability of the weaving business.

\section{Acknowledgment}

The authors would like to thank the Education Fund Management Institution, abbreviated as LPDP (Lembaga Pengelola Dana Pendidikan) the Ministry of Finance of the Republic of Indonesia for funding this research, through the Indonesian Education Scholarship (Beasiswa Pendidikan Indonesia or BPI) for Master's Programmes based on Director's Decree Number KEP15/LPDP/2017, for the 2018-2021 financial year. Also to Universitas Sebelas Maret which have supported this research, as well as resource persons who have provided information during the research.

\section{Declaration of Conflicting Interests}

The authors have declared no potential conflicts of interest concerning the research, authorship, and/or publication of this article.

\section{References}

Coleman, J. S., \& Fararo, T. J. (1992). Rational Choice Theory: Advocacy and Critique. London: SAGE Publications.

Damsar \& Indrayani. (2009). Pengantar Sosiologi Ekonomi. Jakarta: Prenadamedia Group.

Dinas Koperasi, Usaha Kecil dan Menengah Provinsi Jawa Tengah. (2019). Grafik Perkembangan Jumlah UMKM Binaan Provinsi Jawa Tengah TW I 2019. Retrieved from https://dinkopumkm.jatengprov.go.id/v2/statistik/custom/15

Hafidz, A. M. (2015). Keterlekatan Sosial Inovasi Produk Bank Syariah di Indonesia. Jurnal Hukum Islam, 13(2), 70-78. https:/ / doi.org/10.28918/jhi.v13i2.486

Haryanto, S. (2011). Sosiologi Ekonomi. Yogyakarta: Ar-ruz Media.

Hasan, I., He, Q., \& Lu, H. (2020). The impact of social capital on economic attitudes and outcomes. Journal of International Money and Finance. https:/ / doi.org/10.1016/j.jimonfin.2020.102162 
Hedberg, R. C., \& Zimmerer, K. S. (2020). What's the market got to do with it? Social-ecological embeddedness and environmental practices in a local food system initiative. Geoforum, 110, 35-45. https://doi.org/10.1016/j.geoforum.2020.01.022

Jamilah, J., Dharmawan, A. H., Panjaitan, N. K., \& Damanhuri, D. S. (2016). Keterlekatan Etika Moral Islam dan Sunda dalam Bisnis Bordir di Tasikmalaya. Sodality: Jurnal Sosiologi Pedesaan, 4(3), 233-241. https:/ / doi.org/10.22500/ sodality.v4i3.14432

Juliansyah, N. (2011). Metodologi Penelitian: Skripsi, Tesis, Disertasi dan Karya Ilmiah. Jakarta: Kencana Prenada Media Group.

Kementerian Koperasi dan Usaha Kecil dan Menengah Republik Indonesia. (2018). Perkembangan Data Usaha Mikro, Kecil, Menengah (UMKM) dan Usaha Besar (UB) Tahun 2017 2018.

Retrieved

from

http:// www.depkop.go.id/uploads/laporan/1580223129_PERKEMBANGAN\%20DATA \%20USAHA \% 20MIKRO, \% 20KECIL,\%20MENENGAH\%20(UMKM)\%20DAN\%20USAHA \%20BESAR\%20(UB)\%20TAHUN\%202017\%20-\%202018.pdf

Kementerian Perindustrian. (2018). Modul Pelatihan 3 in 1 Tenun Kain Goyor. Arsip Modul Pelatihan. Pusdiklat Kementerian Perindustrian - Dinas Perindustrian dan Perdagangan Kabupaten Sragen.

Rahayu, M. (2019). Social Embeddedness and Economic Behaviour in Pesantren Mlangi. Shirkah: Journal of Economics and Business, 4(3), 455-480. http:/ / dx.doi.org/10.22515/ shirkah.v4i3.274

Rohadi, S. (2012). Kerajinan Tenun Goyor Desa Sambirembe sebagai Salah Satu Potensi Wisata di Kabupaten Sragen (Thesis). Universitas Sebelas Maret. Retrieved from https:/ / digilib.uns.ac.id/dokumen/detail/27174/Kerajinan-Tenun-Goyor-Desa-

Sambirembe-Sebagai-Salah-Satu-Potensi-Wisata-di-Kabupaten-Sragen

Salim, H. (2019). Penelitian Pendidikan: Metode, Pendekatan, dan Jenis. Jakarta: Kencana. Sugiyono, S. (2016). Metode Penelitian Kuantitatif, Kualitatif, dan R \& D. Bandung: Alfabeta.

Suyanto, B. (2013). Sosiologi Ekonomi. Kapitalisme dan Konsumsi di Era Masyarakat PostModernisme. Jakarta: Prenadamedia Group.

\section{About the Authors}

1. Meita Arsita, a graduate student at Master of Sociology, Faculty of Social and Political Sciences, Universitas Sebelas Maret, Indonesia.

E-Mail: meitaarsita28@student.uns.ac.id

2. Ahmad Zuber, obtained his Doctoral degree from Universitas Brawijaya, Indonesia, in 2011. The author is an Associate Professor at the Department of Sociology, Faculty of Social and Political Sciences, Universitas Sebelas Maret, Indonesia.

E-Mail: a.zuber@staff.uns.ac.id

3. Argyo Demartoto, obtained his Doctoral degree from Universitas Gadjah Mada, Indonesia, in 2012. The author is an Associate Professor at the Department of Sociology, Faculty of Social and Political Sciences, Universitas Sebelas Maret, Indonesia.

E-Mail: argyodemartoto_fisip@staff.uns.ac.id 